$\begin{array}{ll} & \text { Preprints are preliminary reports that have not undergone peer review. } \\ \text { Research Square } & \text { They should not be considered conclusive, used to inform clinical practice, } \\ \text { or referenced by the media as validated information. }\end{array}$

\title{
Evaluation of Indicators for Cyanobacterial Risk in 108 Temperate Lakes Using 23 Years of Environmental Monitoring Data
}

JING LI ( $\square$ jing.li@tvrl.Ith.se)

Lunds Universitet https://orcid.org/0000-0001-9632-0452

Kenenth M Person

Lund University

Heidi Pekar

National Food Agency

Daniel Jansson

Swedish Defence Resaerch Agency

\section{Research}

Keywords: total phosphorus, cyanobacteria, cyanotoxins, nonlinear quantile regression

Posted Date: November 9th, 2020

DOI: https://doi.org/10.21203/rs.3.rs-103109/v1

License: (c) (i) This work is licensed under a Creative Commons Attribution 4.0 International License. Read Full License

Version of Record: A version of this preprint was published at Environmental Sciences Europe on April 23rd, 2021. See the published version at https://doi.org/10.1186/s12302-021-00483-1. 


\section{Abstract}

Background: Cyanobacterial blooms are of increasing concern for drinking water supply. Cyanobacterial risk in 108 temperate freshwater lakes were examined for drinking water supply.

Results: In Sweden, a survey among drinking water producers showed that the sense of urgency was little. At $60 \%$ of the Swedish drinking water treatment plants, operators lacked monitoring strategies. The study shows that blooms can produce a variety of toxins such as anatoxins, cylindrospermopsins, microcystins and saxitoxins. We confirmed the anthropogenic activities' impact on cyanobacterial risk and evaluated that total phosphorus (TP) concentration can be used to indicate cyanobacterial risk by applying non-linear quantile regression for 108 Swedish monitoring lakes.

Conclusion: We suggest that TP concentration should be investigated thoroughly to provide important knowledge which can be used to set nutrient targets to sustain safe drinking water supply and recreational services.TP should be targeted lower than $15 \mu^{\mathrm{g} \mathrm{L}^{-1}}$, allowing $10 \%$ exceedance of WHO Drinking Water Alert Level 1.

\section{Background}

Globally, the frequency and intensity of cyanobacterial blooms in fresh water bodies are increasing due to eutrophication caused by anthropogenic nutrient enrichment and climatic induced changes (Paerl et al., 2011). These consequently have a huge impact on the ecosystem (Chaurasia, 2015), but they also have an impact on human activities. For example, fishing activities are negatively affected by clogging fishing-nets and drinking water treatment plants get operational problems by clogging raw water strainers and causing unpleasant odour and taste in the treated water (E. Willén, 2001). Above all, public health concern regarding cyanobacteria is intensified since some cyanotoxins produced by cyanobacteria cause severe and irreversible health effects (I Chorus \& Cavalieri, 2000; Merel et al., 2013; Svrcek \& Smith, 2004). The major exposure routes of cyanotoxins to humans are food, recreational swimming, and poorly treated drinking water.

In Sweden, half of the drinking water supply is based on surface water sources, which can be a problem since harmful cyanobacterial blooms have been frequent. Specifically, there is a risk that existing water purifiers fail to remove the toxic cyanobacteria, particularly at small water treatment plants (Radio Sweden, 2018; The Local, 2018). Thus, it is of great importance for drinking water operators to develop strategies to cope with cyanobacterial risk. This is also highlighted for operators following Water Safety Plans (WSPs) in combination with Hazard Analysis and Critical Control Points (HACCP) (Bartram et al., 2009) and emphasized by the Swedish Food Agency. Decision making suggestions to counteract drinking water containing critical levels of cyanotoxins are provided, including a thorough understanding on how cyanobacteria blooms occur, what cyanotoxins are available, action limits for cyanotoxins in drinking water, to what extent the different drinking water preparation steps separate or inactivating cyanotoxins as well as sampling and analysis of cyanotoxins (Livsmedelsverket, 2018). A challenge in this respect is the fact that many Swedish drinking water treatment plants (DWTPs) were built in the 1950ies of 1960ies, adapted to clearer water from the lakes during that time. As cyanobacterial blooms in freshwaters is a global issue, the knowledge can be used as inspirations for international comparison.

An interesting source of data to investigate how common cyanobacterial blooms are in Swedish lakes is the list of so-called trend lakes in the environmental monitoring program managed by Swedish Agency for Marine and Water Management (SwAM) and operated by Swedish University of Agriculture Science (SLU) (Fig. 1). The lakes are reference lakes in terms of point sources and intensive different local land use, and also may be affected by large-scale airborne pollution and extensive land use (Folster et al., 2014). Different toxins may be present in the waters. Previous investigation showed that most of the cyanobacterial blooms in the Swedish lakes produce a variety of toxins including anatoxins,

cylindrospermopsins, microcystins and saxitoxins (Pekar et al., 2016).

The aim of this project is to get a picture of the size of the problem in these 108 SwAM trend lakes utilizing the 23 years of environmental monitoring data. The purpose is to understand how cyanobacteria abundance interact with water chemistry and physical condition to find local measures for indicating/predicating, monitoring, and controlling cyanobacteria risk. The hypothesis is that the total phosphorus concentrations in the lakes are of importance. Can total phosphorus concentration be used to indicate cyanobacterial risk instead of chlorophyll-a and transparency? In order to achieve this aim, a survey was also carried out with 98 drinking water treatment plants (DWTPs) to understand what methods are used by drinking water producers to analyse cyanobacteria and/or cyanotoxins and their monitoring strategies and frequencies.

\section{Methods}

\section{Survey of drinking water producers concerning monitoring of Cyanobacteria or Cyanotoxins}

An electronic survey, with the following questions, was distributed to 98 Swedish drinking water producers where surface waters are used as raw water to the treatment plant.

1) Do you monitor the presence of cyanobacteria (blue-green algae) on a regular basis? 
2) Do you systematically follow up the presence of Cyanobacteria?

3) Are you analysing the presence of Cyanobacteria in raw water?

4) Do you analyse the presence of Cyanobacteria in drinking water?

5) Are you using rapid methods (dip-sticks) to measure the abundance of microcystins?

6) If yes in 5), what type?

\section{Sampling}

SwAM trend lakes is part of the freshwater programme within the Swedish National Environmental Monitoring Scheme. The sampling details are described by Swedish University of Agricultural Sciences (Department of Aquatic Sciences and Assessment, 2019). A brief summary is given here. Phytoplankton was sampled yearly in August between 1995-2018 in 108 lakes across Sweden of varying sizes (Fig. 1), including 49 lakes < 0.5 km², 21 lakes $>0.5$ to $1 \mathrm{~km}^{2}$ and 38 lakes $>1 \mathrm{~km}^{2}$. All qualitative samples were taken at the lake surface, using a landing net, in the centre of the lake to determine the composition of phytoplankton species and community. Total biomass and biomass of the different species were analysed in the quantitative samples which were collected using a $2 \mathrm{~m}$ tube sampler. Samples were collected in the photolytic zone between 0-5 meters. In larger lakes $\left(>1 \mathrm{~km}^{2}\right)$, the sample was taken at the centre of the lake while in smaller lakes $\left(<1 \mathrm{~km}^{2}\right)$ samples at five different locations were taken and then mixed to a composite sample. Surface water samples for water chemical analysis were collected using a Ruttner water sampler.

\section{Biological and chemical analysis}

The analysis of phytoplankton comprised 14 classes, with quantitative measures of bio-volume per water volume by using Utermöhl technique (Utermöhl, 1958). The methods for species and sub species identification are described elsewhere (Guiry, 1995). The data used in this study is hosted by the Swedish University of Agricultural Sciences and available through open access (http://miljodata.slu.se/). Relevant parameters for this work are: Cyanobacteria biovolume, Chlorophyll-a, Transparency, Total Phosphorus, Total Nitrogen, Total Organic Content (TOC), pH, Fe, Si, Alkalinity/Acidity, and Conductivity. Analysis methods for chemical parameters including measurement uncertainty are presented in details elsewhere ("Laboratoriet för geokemi (Vattenkemiska laboratoriet) | Externwebben," n.d.).

\section{WHO guideline values}

WHO $(1999,2003,2015)$ recommends 'a series of guideline values associated with incremental severity and probability of health effects'(Ingrid Chorus \& Bartram, 1999; WHO, 2003; World Health Organization, 2015). WHO thresholds for cyanobacterial abundance in recreational waters and drinking waters were applied to identify cyanobacterial risk.

\section{Drinking Water Alert Level 1}

cyanobacterial biomass as 2,000 cells per $\mathrm{ml}$ or $0.2 \mathrm{~mm}^{3} \mathrm{~L}^{-1}$ biovolume or $1 \mu \mathrm{g} \mathrm{L}^{-1}$ chlorophyll-a. It requires an assessment of potential toxic cyanobacteria concentration and toxins and consultation with health authorities for ongoing assessment of the status of the bloom and of the suitability of treated water for human consumption. Weekly monitoring is suggested throughout the source water body.

\section{Drinking Water Alert Level 2}

cyanobacterial biomass of 100,000 cells per $\mathrm{ml}$ or $10 \mathrm{~mm}^{3} \mathrm{~L}^{-1}$ bio-volume or $50 \mathrm{\mu g} \mathrm{L}^{-1}$ chlorophyll-a (with the presence of toxins confirmed by chemical or bioassay techniques). It describes an established and toxic bloom with high biomass and possibly also localised scums. Effective treatment is required, alternative drinking water source should be suggested and more extensive media releases of the emergency information, and even direct contact with consumers.

Thresholds for recreational waters: three health alert categories: low $\left(<2 \mathrm{~mm}^{3} \mathrm{~L}^{-1}\right)$, moderate $\left(2 \mathrm{~mm}^{3} \mathrm{~L}^{-1}\right.$ to $\left.10 \mathrm{~mm}^{3} \mathrm{~L}^{-1}\right)$ and high $\left(>10 \mathrm{~mm}^{3} \mathrm{~L}^{-1}\right)$. A high alert (or high probability of adverse health effects) is assigned when surface scums are present, where cell densities and toxin concentrations can be very high and severe health risks are possible. The 'low' and 'moderate' probabilities of adverse health effects are associated with less severe symptoms such as skin irritations and gastrointestinal illness.

\section{Statistical analysis}

The Mann Kendall Trend Test ( $M-K$ test) is used to analyse data collected over time for consistently increasing or decreasing trends (monotonic) in response values. It is a non-parametric test, which means that it works for all distributions. Change point analyser was used to check significant break point of a time series data ("Change-Point Analyzer - Taylor Enterprises," n.d.). Principle component analysis (PCA) was used to gain knowledge of the key water quality information and find out how significant the cyanobacterial condition in the selected 9 lakes plus a reference lake, in total 10 lakes, and which factors mostly relevant to its presence. 


\section{Quantile regression}

Quantile regression aims to estimate either the conditional median or other quantiles of the response variable. The advantage of quantile regression is that its estimates are robust against outliners in the response measurements, facilitating a more comprehensive analysis of the relationship between variables (Koenker \& Hallock, 2001). Its application for example in ecology, has been proposed to discover more useful predictive relationship between variables, particularly in cases where no relationship or only a weak relationship is expected. It has been successfully contributing to the understanding of the complexity of interactions between different factors leading to data with unequal variation of one variable for different ranges of another variable (Cade \& Noon, 2003). Its application is highlighted in a large European project to derive a quantitative understanding of total phosphorus on cyanobacterial abundance in over 800 European freshwater lakes and set nutrient targets to sustain recreational services and more (Carvalho et al., 2013). In this project, quantile regression is used to study the situation of nutrients influence on cyanobacterial abundance in these SwAM trend lakes and set nutrient target to sustain both recreational and drinking water services and provide different levels of precaution for decision making.

Software R offers several packages that implement quantile regression, most notably quantreg by Roger Koenker (Roger et al., 2019). In this project non-linear quantile regression is used by applying Self-Starting Nls Logistic Model (SSlogis). SSlogis as selfStart model evaluates the logistic function and its gradient. It has initial attributes as initial estimates of the parameters Asym, Xmid and scal. The equation used is

$\log 10($ cyanobacteria +1$)=$ Asym $/(1+\exp ((x m i d-l o g 10(T P)) / s c a l))($ Eq. 1.)

Where, Asym a numeric parameter representing the asymptote.

Xmid a numeric parameter representing the TP value at the inflection point of the curve. The value of SSlogis will be Asym/2 at xmid.

Scal a numeric scale parameter on the input axis.

\section{Results}

\section{Survey of drinking water producers concerning monitoring of Cyanobacteria or Cyanotoxins}

A survey was sent out to 98 DWTPs. 77 of the DWTPs (79\%) participated. 62 of them completely lacked monitoring program or had any other type of surveillance for cyanobacteria and/or cyanotoxins. 3 of them performed ocular inspections for the presence of algal bloom or cyanobacteria in the surface water and/or at the raw water intake. 6 of them monitored the concentration of the cyanotoxin microcystin at the raw water intake and lastly, 6 of them were monitoring the presence of cyanobacteria and/or cyanotoxins occasionally. On indication of cyanobacteria in raw water, 3 of them followed up with analysis of microcystins also in the drinking water. Such indications were, most commonly, identification of potentially toxin producing cyanobacteria by microscope. The sense of urgency concerning problems with blooms was low.

\section{General distribution of cyanobacterial biomass}

High occurrence of cyanobacteria (i.e. median value $>0.2 \mathrm{~mm}^{3} \mathrm{~L}^{-1}$ ) present in 9 lakes ( $8 \%$ of SwAM trend lakes) mainly located in south of Sweden (Fig. 1). Lillsön has the highest median value and more than $60 \%$ of the cases, cyanobacteria are dominating (>50\%). Krageholmssjön has the largest variance. All 108 lakes cyanobacterial biomass values with minimum, maximum and median refer to Tab.S1. Land use and ecosystem statues of those 9 lakes are summarized in Tab. S2, which indicates that those 9 lakes are categorized as having bad or unsatisfied ecosystem, high eutrophication statues and intensive land use.

\section{Trend of cyanobacteria in selected lakes}

No significant trend for cyanobacterial biomass distribution was found in the past 23 years in those 9 lakes, which could be verified by Mann-Kendall trend test. Significant variations however were found in Lillsjön shown in Fig. S1. The average value of cyanobacterial biomass varied from 11 mm ${ }^{3}$ $\mathrm{L}^{-1}$ (1995 to 2003) to $2.8 \mathrm{~mm}^{3} \mathrm{~L}^{-1}$ (2003 to $\left.2013, \mathrm{P}<0.01\right)$ and back to $9.5 \mathrm{~mm}^{3} \mathrm{~L}^{-1}$ (2014 to $2017, \mathrm{P}<0.03$ ).

\section{What are the most frequent species and potential toxins?}

Cyanobacterial species were analysed in samples with a biovolume $>0.2 \mathrm{~mm}^{3} \mathrm{~L}^{-1}$ (424/ 2410 samples from 1995 to 2018$)$ to investigate the most frequent taxa (Fig. 2A) and species (Fig. 2B). Anabaena and Aphanizomenon were the most frequent taxa, followed by Microcystis and Woronichinia and Planktothrix agardhii. Tab. S3 summarizes literature study (Tab. S4) of potential toxins produced by the most frequent cyanobacterial species. The species identified in Fig. 2B have the potential to produce several variants of anatoxins, cylindrospermopsins, microcystins and saxitoxins. As the most frequent cyanobacterial species comprise almost $90 \%$ of the occurrence, it indicates that cyanobacteria biovolume $>0.2 \mathrm{~mm}^{3} \mathrm{~L}^{-1}$ in those lakes were potentially toxic. 


\section{How eutrophication states impact the diversity of cyanobacteria species}

Figure 3 illustrates the diversity of cyanobacteria species in the 9 lakes plus Lake V. Rännöbodsjön as a reference lake. The figure shows that the more eutrophic the water is, the more diverse the cyanobacteria taxa are. Significant correlation (0.54) between TP and the number of cyanobacterial taxa was found. The reference lake with the lowest level of phosphorus has only one specie while the lake with highest level of phosphorus, Krageholmssjön, has more than 7 taxa.

\section{Which parameters are playing important roles in cyanobacterial blooms?}

Investigation of primary water information and important factors were done by Pearson correlation and PCA analysis. Pearson correlation matrix in Fig. S2 shows the correlations between cyanobacteria biomass and other water quality parameters, where cyanobacterial biomass is positively (in order) correlated with TP, chlorophyll-a, TOC, alkalinity condition and TN; and strongly negatively correlated with transparency. This is also confirmed by PCA analysis in Fig. S3; and variables that significantly correlated to each component are highlighted in Tab. S5. The first main component which accounts for $42 \%$ variance of original data reflects prior information in those lakes are nutrients condition and total plankton biomass and they are positively connected, particularly in lakes surround by agriculture land. The second main component explains $27 \%$ of the variance of the original data and reflects the cyanobacterial condition, which is significantly positively connected to the total organic matter and Fe content, particularly in lakes surrounded by forestry lakes, and are negatively correlated with transparency, $\mathrm{pH}$ and conductivity. Thus, it might indicate that the increase of cyanobacteria would increase together with TOC and Fe in water, causing water deterioration.

Figure S3 also illustrates clearly that lakes surrounded by more forest form a distinct cluster on the top left, and lakes that are surrounded by more agricultural land, are clustered in the bottom right. Forestry lakes are closer to high cyanobacterial biomass and cyanobacteria dominating situation, total organic matter and Fe. Lakes surrounded by agriculture land are closer to nutrient condition. Besides, two lakes are very distinct from others, one is a lake with mixed land use (Ymsen), located in-between the two clusters and a reference lake (V. Rännöbodsjön) with comparatively clearer water is located far from all others.

\section{Evaluation transparency and chlorophyll-a as indicator for cyanobacterial presence}

Transparency and chlorophyll-a are listed as important factors for assessing the potential presence of cyanobacterial biomass in water among other indicators such as total phosphorus, water residence time, temperature and pH (Kreakie et al., 2015; Lee \& Lee, 2018; World Health Organization, 2015). If transparency is low (less than 1-2 $\mathrm{m}$ ) and accompanied by a blue and green water colour, high cyanobacterial biomass is likely. A chlorophyll-a concentration of $1 \mu \mathrm{g} \mathrm{L}^{-1}$ in raw water triggers Alert Level 1 in WHO management system for cyanobacterial blooms in the perspective of drinking water (Ingrid Chorus \& Bartram, 1999). Taste and odour problems begin occurring once chlorophyll-a values reach $10 \mu \mathrm{g} \mathrm{L}{ }^{-1}(\mathrm{KDHE}$ (Kansas Department of Health and Environment Bureau of Water), 2011).

A general overview of transparency and chlorophyll-a concentration with cyanobacterial biomass in the 9 lakes are presented in boxplot (Fig. S4 and S5) with drinking water alert levels and health thresholds. In general, when transparency decreases, it is likely to trigger higher alert levels and health thresholds; and the more chlorophyll-a content in water, the more likely higher cyanobacterial biomass present. In the selected 9 lakes, an average transparency as $1.2 \mathrm{~m}$ and chlorophyll-a median value as of $32 \mathrm{\mu g} \mathrm{L}^{-1}$ correspond in general to their high cyanobacteria occurrence. From specific lake study, high correlation between transparency and cyanobacterial risk are only found in Lillsjön (-0.75) and Ymsen (-0.70). A high correlation between chlorophyll-a and cyanobacterial risk are only found in Krankesjön (0.85) and Tångerdasjön (0.79).

Significant indicators for the variance of cyanobacterial biomass might be different in different lakes, for example, Iron and pH for Edasjön, conductivity for Krageholmssjön and pH condition for Rundbosjön.

\section{Phosphorus control for maximizing drinking water safety and minimizing health risks from cyanobacterial blooms.}

Quantile regression curves (0.05-0.99) using a fitted 3-parameter sigmoid nonlinear model are displayed in Fig. 4 by using all 108 lakes' data. All quantiles, including lower quantile (0.05), show significant relationship between cyanobacteria biomass and TP (Table 1). This relationship differs from Carvalho and his colleagues' study, involving more than 800 European lakes (Carvalho et al., 2013), in which a significant relationship was only present in higher quantiles ( 0.25 and above). Figure 4 shows that the higher the quantile, the earlier the take-off of cyanobacteria response to TP. For example, the 95th quantile and 75th quantile have a take-off of cyanobacteria response at a threshold around $10 \mu \mathrm{g} \mathrm{L}-1$, while for the 50 th and 25 th quantile, cyanobacteria start to response at TP around $30 \mu \mathrm{L} \mathrm{L}^{-1}$. All quantiles have a flattening of response at a threshold about $100 \mu \mathrm{g} \mathrm{L}^{-1}$. It means that the increase of TP after this point have low impact on additional cyanobacteria growth. 
Table 1

correlation matrix of quantile estimates and phosphorus concentrations.

\section{Application of quantile responses for predicting bloom capacity}

\begin{tabular}{|lllllll|}
\hline Pearson's product-moment correlation & \multicolumn{2}{l}{ Quantiles } \\
\cline { 2 - 7 } & $\mathbf{0 . 0 5}$ & $\mathbf{0 . 2 5}$ & $\mathbf{0 . 5}$ & $\mathbf{0 . 7 5}$ & $\mathbf{0 . 9 5}$ & $\mathbf{0 . 9 9}$ \\
\hline Correlation with TP concentration & 0.81 & 0.63 & 0.68 & 0.77 & 0.87 & 0.96 \\
\hline P value & $2.2 \mathrm{e}-16$ & $2.2 \mathrm{e}-16$ & $2.2 \mathrm{e}-16$ & $2.2 \mathrm{e}-16$ & $2.2 \mathrm{e}-16$ & $2.2 \mathrm{e}-16$ \\
\hline
\end{tabular}

Quantile regression curves in Fig. 4 can be used to predict the bloom capacity at present temperature regimes. For example, in Table 2, the 95th quantile (i.e. $5 \%$ exceeding rate) is used to estimate the potential maximum capacity of cyanobacteria in response to the increase of TP. In the table, the results show that the capacity for cyanobacteria growth increases with increasing TP, until TP concentrations $>150 \mu \mathrm{g} \mathrm{L}^{-1} ; 5 \%$ of samples would exceed drinking water alert level 1 at TP of $10 \mu \mathrm{L} \mathrm{L}^{-1}$; and exceed low health risk threshold for recreational water at TP of $27 \mu \mathrm{g} \mathrm{L}{ }^{-1}$ and exceed drinking water alert level 2 and medium risk threshold at TP of $53 \mu \mathrm{g} \mathrm{L}-1$.

Table 2

$95 \%$ quantile fitted values showing the changing cyanobacterial biovolume $\left(\mathrm{mm}^{3} \mathrm{~L}^{-1}\right)$ with change in total phosphorous $\left(\mu \mathrm{g} \mathrm{L}^{-1}\right)$. The fitted quantile reaches an asymptote at $38 \mathrm{~mm}^{3} \mathrm{~L}^{-1}$ of cyanobacteria biovolume

\begin{tabular}{|lllllllllll|}
\hline Total Phosphorus $\left(\mu \mathrm{g} \mathrm{L}^{-1}\right)$ & $\mathbf{0}$ & $\mathbf{1 0}$ & $\mathbf{2 7}$ & $\mathbf{5 3}$ & $\mathbf{1 0 0}$ & $\mathbf{1 5 0}$ & $\mathbf{2 0 0}$ & $\mathbf{2 5 0}$ & $\mathbf{3 0 0}$ & $\mathbf{5 0 0}$ \\
\hline Cyanobacteria capacity $(95 \%)\left(\mathrm{mm}^{3} \mathrm{~L}^{-1}\right)$ & 0 & 0.2 & 2 & 10 & 25 & 32 & 35 & 36 & 37 & 38 \\
\hline
\end{tabular}

\section{Nutrient targets in relation to alert levels for drinking water and health risk for recreational water}

By applying quantiles algorithms with quantiles $>0.5$ in Table 3, nutrients targets are calculated in relation to alert levels for drinking water and health risk thresholds. The results in Table 4 demonstrates that at a TP of about $14 \mu \mathrm{g} \mathrm{L}-1,10 \%$ of samples exceeded the WHO drinking water alert level 1, if TP increases to $35 \mathrm{\mu g} \mathrm{L}^{-1}$, the percentage of exceedance will be $50 \%$. Similarly, $10 \%$ of water samples would surpass low health risk for recreational water $\left(2 \mathrm{~mm}^{3} \mathrm{~L}^{-1}\right)$, at TP level of $35 \mu \mathrm{g} \mathrm{L}^{-1}$, at a level of around $60 \mu \mathrm{gL}^{-1}$, the percentage of exceedance will be $50 \%$. In the same way, it shows at a TP concentration level of $72 \mu \mathrm{g} \mathrm{L}-1,10 \%$ of samples would surpass the drinking water alert level 2 and medium health risk.

Table 3

Parameter estimates derived using nonlinear quantile regression for 108 Swedish trend lakes together with the estimates for nonlinear mean response. The rest $\mathrm{P}<0.01, * \mathrm{p}<0.05$

\begin{tabular}{|llll|}
\hline Model & Asym & mid & Scal \\
\hline 0.05 & $0.09 \pm 0.04$ & $1.77 \pm 0.15$ & $0.19 \pm 0.02$ \\
\hline 0.25 & $0.36 \pm 0.15 *$ & $1.86 \pm 0.12$ & $0.09 \pm 0.03$ \\
\hline 0.5 & $0.67 \pm 0.09$ & $1.70 \pm 0.04$ & $0.07 \pm 0.01$ \\
\hline Mean (Non-linear) & $0.71 \pm 0.03$ & $1.70 \pm 0.02$ & $0.14 \pm 0.01$ \\
\hline 0.75 & $1.23 \pm 0.19$ & $1.79 \pm 0.06$ & $0.17 \pm 0.01$ \\
0.95 & $1.61 \pm 0.23$ & $1.62 \pm 0.09$ & $0.21 \pm 0.02$ \\
\hline 0.99 & $1.71 \pm 0.22$ & $1.41 \pm 0.11$ & $0.26 \pm 0.04$ \\
\hline
\end{tabular}

Table 4

Total phosphorus (TP) concentrations for a given likelihood (quantile) of being below low and medium risk World Health Organisation (WHO 1999) threshold levels for cyanobacteria volume. TP concentrations are obtained from the fitted quantile regression models

\begin{tabular}{|c|c|c|c|c|c|c|c|c|}
\hline Quantile & & 50th & 60th & 70th & 80th & 90th & 95th & 98th \\
\hline$\%$ exceeded & & $50 \%$ & $40 \%$ & $30 \%$ & $20 \%$ & $10 \%$ & $5 \%$ & $2 \%$ \\
\hline Drinking water alert $10.2 \mathrm{~mm}^{3} \mathrm{~L}^{-1}$ & $\mathrm{TP} \mu \mathrm{gL}^{-1}$ & 35.34 & 30.31 & 23.90 & 19.39 & 13.42 & 10.25 & 5.87 \\
\hline Low health risk $2 \mathrm{~mm}^{3} \mathrm{~L}^{-1}$ & $\mathrm{TP} \mu \mathrm{gL}^{-1}$ & 57.88 & 56.15 & 53.58 & 48.69 & 35.44 & 27.84 & 19.33 \\
\hline Drinking water alert 2/Medium health risk $10 \mathrm{~mm}^{3} \mathrm{~L}^{-1}$ & $\mathrm{TP}_{\mu} \mathrm{gL}^{-1}$ & & & & 117.30 & 72.15 & 56.11 & 43.99 \\
\hline
\end{tabular}


By applying results from Table 4 to our selected 9 lakes, of which all median value of TP above $33 \mu \mathrm{g} \mathrm{L}-1$, that least $40 \%$ exceedance rate above the drinking water alert level 1 and 10\% exceedance rate above the low health threshold. Lake Krageholmssjön with the highest median value of TP, around $129 \mathrm{\mu g} \mathrm{L}^{-1}$, it is more than $20 \%$ likely to above the medium health risk and drinking water alert level 2. TP target for low health risk in SwAM trend lakes allow $10 \%$ exceedance is $35 \mathrm{\mu gL}^{-1}$.

\section{Discussion}

\section{TP as indicator for cyanobacterial risk}

Phosphorus control is the key to control cyanobacterial blooms and consequent health risk, which has been highlighted in many research projects (Li et al., 2018; Morris \& Lewis, 1988; Xu et al., 2015) and used in practice at for example Lake Erie (Water Canada, 2018) and Vombsjön, South Sweden(Li et al., 2019). It is important to understand more fully the response of cyanobacterial abundance in relation to nutrient pressures (Li et al., 2017). Our study verified the advantage of using quantile regression for a quantitative study of the cyanobacteria response of TP in a Swedish context. Compared to Carvalho and his colleagues' study (Carvalho et al., 2013), the application even suits low quantiles models. The algorithm and calculations in the results would facilitate water operators for decision making regarding to TP targets.

As we noticed that from a drinking water point of view, under $10 \%$ exceedance rate, TP target would be reduced less than $15 \mu \mathrm{L} \mathrm{L}^{-1}$, and for recreational purpose, under $10 \%$ exceedance rate, TP target for low health risk is $35 \mathrm{gg} \mathrm{L}^{-1}$ which is higher than Carvalho and his colleagues' study (Carvalho et al., 2013), which is $20 \mu \mathrm{gL}^{-1}$. Two studies also differ in the cyanobacteria growth in response to TP in the low quantiles that significant correlation between them was found in Swedish trend lake while not in Carvalho and his colleagues' study.

Those differences might due to other factors also play important role in cyanobacteria growth in a more diverse lake group, such as temperature, sun radiation and salinity, etc. In a colder climate in Sweden, cyanobacteria growth in lakes might be more driven by nutrients condition, low temperature could be a limiting condition; TP is expected to be higher to reach the same impact on cyanobacteria growth.

\section{Challenges of cyanobacterial risk monitoring and predicting}

Even though, above quantile regression has demonstrated its advantage and usefulness to indicate cyanobacterial risk over single factor such as transparency or chlorophyll-a, we still need to keep in mind that various environmental factors are influencing cyanobacteria abundance such as temperature, wind, land use, DO, salinity, and pH, lake geometry, species competition, grazers as well as their various surviving strategies (Reynolds, 2006).

No clear trend of cyanobacteria occurrence and the diversity of toxic species have added complexity of managing cyanobacterial issue in eutrophic waters. The likelyhood of increase of co-occureance of multi-toxin producing species with increase of eutrophication were also observed in a large scale Finnish lakes' study (Rantala et al., 2006).

\section{Land use impact on cyanobacteria}

All the problematic 9 lakes are highly affacted by anthropogenic activities. They are also categorized as having bad or unsatisfied ecosystem status mainly due to high eutrophication, highly influenced by urbanization, agriculture and historically exposed for not well treated wastewater (Water information system, 2019). PCA analysis results showed that there is a clear difference between agricultural lakes and forestry lakes; the former is more eutrophic, and the latter is browner (more organic matter).

Our results emphasize that besides nutrients which are essential condition for cyanobacterial growth, the organic matter has high correlation with the cyanobacteria abundance particularly in eutrophic forestry lakes. The increase of iron bond TOC in eutrophic forestry lakes might trigger even more intensive cyanobacterial blooms. It brings worries under future climate scenarios that the increase of brownification (increase of organic matter in water), particularly in the northern hemisphere (Kritzberg et al., 2019) together with the increase of temperature might trigger more intensive cyanobacterial blooms(Urrutia-Cordero et al., 2016).

\section{Opportunities of cyanobacteria monitoring}

Other studies have also shown poor correlation between chlorophyll-a and bio-volume of cyanobacteria; rather phycocyanin could be recommended as an early warning signal (Randolph et al., 2008) and direct measurement of specific chlorophyll-a in cyanobacteria cells by their specific fluorescence spectra became popular such as application of Algae Online Analyzer (AOA) fluorometer (Izydorczyk et al., 2009). Such fluorometer can simultaneously distinguishes four different phytoplankton groups by their specific fluorescence spectra and thus allows for real-time in-situ chlorophyll-a measurements per algal group. At the end, other elements also showed their importance in relation to cyanobacterial biomass formation. Individual lake investigation and deeper understanding of the individual lakes is crucial for setting indicators or building predicting models.

\section{The sense of urgency concerning problems with blooms was low.}


The current management situation would have been changed as the survey was done in 2016 within a national project for a purpose of reinforcing the ability of drinking water producers for hazard analysis and risk management in toxic algal bloom in water supply (2016-2018), of which guidance and handbooks were produced to facilitate water operators for cyanobacteria and cyanotoxin management (Livsmedelsverket, 2018; Swedish National Food Authority, 2019).

\section{Guidelines and regulations applied}

The WHO thresholds adopted in this study (WHO 1999, 2003, 2004) are not the only targets that exist. For example, in Finland, DWTPs are recommended to increase monitoring actions and preparedness when the biomass exceeds $0.1 \mathrm{~mm}^{3} \mathrm{~L}^{-1}$ in incoming raw water (I Chorus, 2012). When the biomass exceeds $1 \mathrm{~mm}^{3} \mathrm{~L}^{-1}$, DWTPs are recommended to take action such as to change the abstraction point or depth, identify species of cyanobacteria or potential cyanotoxins, perform a health risk assessment and inform the municipal health protection authority (I Chorus, 2012). While Australia set at a total bio-volume equivalent of $4 \mathrm{~mm}^{3} \mathrm{~L}^{-1}$ as health alert levels, although skin irritations have been observed at densities as low as $0.4 \mathrm{~mm}^{3} \mathrm{~L}^{-1}$ (Pilotto et al., 2004).

\section{Limitations and other concerns}

Among SwAM trend lakes, only 8\% lakes displayed problematic cyanobacteria abundance between 1995 - 2018 . The percentage cannot be extrapolated and cannot be applied to source waters for drinking water supply since the selection criteria for trend lakes and source water for drinking water production are different. Trend lakes were selected with the purpose of tracing environmental changes amongst other, climate change, and the majority of them are located in rural areas. Source waters for drinking water production are often located close to cities and in general more impacted by anthropogenic activities than many of the Swedish trend lakes.

There is no clear trend of cyanobacteria abundance in those lakes during the monitoring period, partly due to data limitation. As sampling was done once per year in August, implying that trend lakes blooming at other times would not appear as a blooming lake in this study. In Sweden the main bloom period for cyanobacteria starts in May and continues through August, even into the middle of November. For example, Aphanizomenon was abundant also in November and Planktothrix agardhii has been identified in considerable volumes during winter in some lakes (T. Willén \& Mattsson, 1997). The value of long- term monitoring program has also been questioned and summarized by Lovett and others (Lovett et al., 2007). For a better understanding of the cyanobacterial abundance in SwAM trend lakes, particularly in those highlighted 9 lakes, sample frequency should be increased, at least to cover the bloom season.

\section{Suggestions for local water operators}

Study your lake individually and find a proper indicator or a combination of indicators that fit your situation for better monitoring cyanobacteria abundance. Set a routine to check total phosphorous, cyanobacteria abundance, composition and cyanotoxin content and trace their variations. Advanced treatment might be introduced, or alternative water resources should be investigated.

\section{Conclusion}

Cyanobacterial blooms are of increasing concern, not least when using water for bathe or water supply. Blooms may clog filters, bring odour and unpleasant taste to the treated water and worst of all, cause elevated cyanotoxin concentrations in the water which can be extremely difficult to remove, yet lead to severe and irreversible health issues. A survey among drinking water producers in Sweden showed that the sense of urgency was little. To get a picture of the size of the problem the presence of cyanobacterial blooms in 108 Swedish trend lakes was evaluated from 23 years of environmental monitoring data. The evaluation shows that blooms could produce a variety of toxins such as anatoxins, cylindrospermopsins, microcystins and saxitoxins. The most common taxa discovered were Anabaena/Dolichospermum and Aphanizomenon followed by Microcystis, Woronichinia and Planktothrix. The more eutrophic the lake, the more likely multispecies dominate. In eutrophic forestry lakes, cyanobacterial biovolume tends to increase with the increase of organic matter. We further evaluated that chlorophyll-a and transparency might be suitable as indicators for cyanobacterial blooms in certain lakes, while for most of the lakes, their connection is low. Applying non-linear quantile regression is highlighted in our study to demonstrate how the cyanobacterial growth capability response to TP concentration for all 108 SwAM trend lakes. Our results conclude that allowing $10 \%$ exceedance, for WHO drinking water alert level 1 , TP should be targeted lower than $15 \mu \mathrm{L} \mathrm{L}^{-1}$; for recreational purpose, TP target for low health risk is $35 \mu \mathrm{g} \mathrm{L}^{-1}$. We suggest TP concentrations should be investigated thoroughly to provide important knowledge which can be used to set nutrient targets to sustain safe drinking water supply and recreational services. Individual lake study is necessary to find a proper or a combination of indicators that fit local situation for better indicating cyanobacteria abundance.

\section{List Of Abbreviations}

TP: Total Phosphorus

SwAM: Swedish Agency for Marine and Water Management

DWTPs: drinking water treatment plants 
WSPs: Water Safety Plans

HACCP: Hazard Analysis and Critical Control Points

AOA: Algae Online Analyzer

\section{Declarations}

\section{- Ethics approval and consent to participate}

Not applicable

\section{- Consent for publication}

Not applicable

\section{- Availability of data and material}

The datasets generated and/or analysed during the current study is open source data downloaded from a national environmental data platform https://miljodata.slu.se/MVM/Search

\section{- Competing interests}

No

\section{- Funding}

The project is partly funded by a project $₫$ Methods for Early Warning and Crisis preparedness for Cyanotoxins in drinking water (SOFÄ $12-24)$ funded by the Swedish Civil Contingency Service.

\section{- Authors' contributions}

JL: planned the study together with co-authors, performed the statistical analysis, analysed the results and was the main contributor to the writing of all sections and of the discussion and the final review of the paper, with the assistance of the co-authors. K.M.P supervised the project. H.P. was the project manager and coordinated survey study. D.J. performed literature study on the toxin producing species.

\section{- Acknowledgements}

Jesper Svedberg at Swedish National Food Agency is gratefully acknowledged for administrating the electronic survey conducted in this study. Many thanks are given to Lene Nordrum at Lund University for her teaching and instructing scientific writing and polishing manuscript and Sameh Adib Abou Raffee at water resources engineering at Lund University for help with GIS mapping design and Department of Aquatic Sciences and Assessment at SLU for data and basic maps support.

\section{References}

1. Bartram, J., Corrales, L., Davison, A., Deere, D., Drury, D., Gordon, B., et al. (2009). Water safety plan manual: step-by-step risk management for drinking-water suppliers. Retrieved November 27, 2019, from https://apps.who.int/iris/bitstream/handle/10665/75141/9789241562638_eng_print.pdf;jsessionid=D52603E878B1F1B82FB4820FEC556E5B? sequence $=2$

2. Cade, B. S., \& Noon, B. R. (2003). A Gentle Introduction to Quantile Regression for Ecologists. Frontiers in Ecology and the Environment. https://doi.org/10.2307/3868138

3. Carvalho, L., Mcdonald, C., de Hoyos, C., Mischke, U., Phillips, G., Borics, G., et al. (2013). Sustaining recreational quality of European lakes: Minimizing the health risks from algal blooms through phosphorus control. Journal of Applied Ecology. https://doi.org/10.1111/13652664.12059

4. Change-Point Analyzer - Taylor Enterprises. (n.d.). Retrieved December 3, 2019, from https://variation.com/product/change-point-analyzer/

5. Chaurasia, A. (2015). Cyanobacterial biodiversity and associated ecosystem services: introduction to the special issue. Biodiversity and Conservation. https://doi.org/10.1007/s10531-015-0908-6

6. Chorus, I. (2012). Current approaches to Cyanotoxin risk assessment, risk management and regulations in different countries. Compiled and Edited by Dr.Ingrid Chrous, Federal Environemnt Agency, Germany, 174. 
7. Chorus, I, \& Cavalieri, M. (2000). Chapter 10. Cyanobacteria and algae. Monitoring Bathing Waters - A Practical Guide to the Design and Implementation of Assessments and Monitoring Programmes, 205-258.

8. Chorus, Ingrid, \& Bartram, J. (1999). Toxic Cyanobacteria in Water: A guide to their public health consequences, monitoring and management. World Health Organization. https://doi.org/10.1046/j.1365-2427.2003.01107.x

9. Department of Aquatic Sciences and Assessment. (2019). Trend lakes | Externwebben. Retrieved November 5, 2019, from https://www.slu.se/en/departments/aquatic-sciences-assessment/environment/environmental-monitoring-of-lakes-and-watercourses/trendlakes/

10. Folster, J., Johnson, R. K., Futter, M. N., \& Wilander, A. (2014). The Swedish monitoring of surface waters: 50 years of adaptive monitoring Ambio, 43 Supp/ 1, 3-18. https://doi.org/10.1007/s13280-014-0558-z

11. Guiry, M. D. (1995). Algae: A Taxonomic Survey. Phycologia. https://doi.org/10.2216/i0031-8884-34-3-252.1

12. Izydorczyk, K., Carpentier, C., Mrówczyński, J., Wagenvoort, A., Jurczak, T., \& Tarczyńska, M. (2009). Establishment of an Alert Level Framework for cyanobacteria in drinking water resources by using the Algae Online Analyser for monitoring cyanobacterial chlorophyll a. Water Research, 43(4), 989-996. https://doi.org/10.1016/j.watres.2008.11.048

13. KDHE (Kansas Department of Health and Environment Bureau of Water). (2011). Water Quality Standards White Paper - Chlorophyll-a Criteria for Public Water Supply Lakes or Reservoirs, 1-11.

14. Koenker, R., \& Hallock, K. F. (2001). Quantile regression. Journal of Economic Perspectives. https://doi.org/10.1257/jep.15.4.143

15. Kreakie, B. J., Hollister, J. W., Milstead, W. B., Nojavan, F., Hollister, J. W., \& Milstead, W. B. (2015). Predicting related indices of cyanobacteria blooms in lakes based on nutrient inputs and ecosystem attributes. Table Of Contents: Executive Summary:, 1-8.

16. Kritzberg, E. S., Hasselquist, E. M., Škerlep, M., Löfgren, S., Olsson, O., Stadmark, J., et al. (2019). Browning of freshwaters: Consequences to ecosystem services, underlying drivers, and potential mitigation measures. Ambio. https://doi.org/10.1007/s13280-019-01227-5

17. Laboratoriet för geokemi (Vattenkemiska laboratoriet) | Externwebben. (n.d.). Retrieved December 3, 2019, from https://www.slu.se/institutioner/vatten-miljo/laboratorier/vattenkemiska-laboratoriet/

18. Lee, S., \& Lee, D. (2018). Improved prediction of harmful algal blooms in four major South Korea's rivers using deep learning models. International Journal of Environmental Research and Public Health. https://doi.org/10.3390/ijerph15071322

19. Li, J., Parkefelt, L., Persson, K. M., \& Pekar, H. (2017). Improving cyanobacteria and cyanotoxin monitoring in surface waters for drinking water supply. Journal of Water Security, 3, 2345-363005. https://doi.org/10.15544/jws.2017.005

20. Li, J., Hansson, L. A., \& Persson, K. M. (2018). Nutrient control to prevent the occurrence of cyanobacterial blooms in a eutrophic lake in Southern Sweden, used for drinking water supply. Water (Switzerland). https://doi.org/10.3390/w10070919

21. Li, J., Hägg, K., \& Persson, K. M. (2019). The impact of lake water quality on the performance of mature artificial recharge ponds. Water (Switzerland). https://doi.org/10.3390/w11101991

22. Livsmedelsverket. (2018). HANDBOK DRICKSVATTENRISKER Cyanotoxiner i dricksvatten. Uppsala. Retrieved from www.livsmedelsverket.se/publicerat-material/.

23. Lovett, G. M., Burns, D. A., Driscoll, C. T., Jenkins, J. C., Mitchell, M. J., Rustad, L., et al. (2007). Who needs environmental monitoring? Frontiers in Ecology and the Environment. https://doi.org/10.1890/1540-9295(2007)5[253:WNEM]2.0.CO;2

24. Merel, S., Walker, D., Chicana, R., Snyder, S., Baurès, E., \& Thomas, O. (2013). State of knowledge and concerns on cyanobacterial blooms and cyanotoxins. Environment International. https://doi.org/10.1016/j.envint.2013.06.013

25. Morris, D. P., \& Lewis, W. M. (1988). Phytoplankton nutrient limitation in Colorado mountain lakes. Freshwater Biology, 20 (3), $315-327$. https://doi.org/10.1111/j.1365-2427.1988.tb00457.x

26. Paerl, H. W., Hall, N. S., \& Calandrino, E. S. (2011). Controlling harmful cyanobacterial blooms in a world experiencing anthropogenic and climatic-induced change. Science of the Total Environment. https://doi.org/10.1016/j.scitotenv.2011.02.001

27. Pekar, H., Westerberg, E., Bruno, O., Lääne, A., Persson, K. M., Sundström, L. F., \& Thim, A. M. (2016). Fast, rugged and sensitive ultra high pressure liquid chromatography tandem mass spectrometry method for analysis of cyanotoxins in raw water and drinking water-First findings of anatoxins, cylindrospermopsins and microcystin variants in Swedish source wa. Journal of Chromatography A, 1429(January), $265-276$. https://doi.org/10.1016/j.chroma.2015.12.049

28. Pilotto, L., Hobson, P., Burch, M. D., Ranmuthugala, G., Attewell, R., \& Weightman, W. (2004). Acute skin irritant effects of cyanobacteria (bluegreen algae) in healthy volunteers. Australian and New Zealand Journal of Public Health. https://doi.org/10.1111/j.1467-842X.2004.tb00699.x

29. Radio Sweden. (2018). Toxic algae bloom a threat to drinking water. Retrieved November 4, 2019, from https://sverigesradio.se/sida/artikel.aspx?programid=2054\&artikel=7018896

30. Randolph, K., Wilson, J., Tedesco, L., Li, L., Pascual, D. L., \& Soyeux, E. (2008). Hyperspectral remote sensing of cyanobacteria in turbid productive water using optically active pigments, chlorophyll a and phycocyanin. Remote Sensing of Environment.

https://doi.org/10.1016/j.rse.2008.06.002 
31. Rantala, A., Rajaniemi-Wacklin, P., Lyra, C., Lepistö, L., Rintala, J., Mankiewicz-Boczek, J., \& Sivonen, K. (2006). Detection of microcystinproducing cyanobacteria in Finnish lakes with genus-specific microcystin synthetase gene E (mcyE) PCR and associations with environmental factors. Applied and Environmental Microbiology. https://doi.org/10.1128/AEM.01058-06

32. Reynolds, C. S. (2006). The ecology of phytoplankton. The Ecology of Phytoplankton. https://doi.org/10.1017/CBO9780511542145

33. Roger, K., Stephen, P., Pin Tian, N., Achim, Z., Hilip, G., Cleve, M., \& Brian D, R. (2019). quantreg: Quantile Regression.

34. Svrcek, C., \& Smith, D. W. (2004). Cyanobacteria toxins and the current state of knowledge on water treatment options: a review. Journal of Environmental Engineering and Science. https://doi.org/10.1139/s04-010

35. Swedish National Food Authority. (2019). Algblomning - cyanobakterier. Retrieved November 4, 2019, from https://www.livsmedelsverket.se/livsmedel-och-innehall/oonskade-amnen/cyanobakterier-blagrona-alger/

36. The Local. (2018). Algal bloom a problem for drinking water in Sweden - The Local. Retrieved November 4, 2019, from https://www.thelocal.se/20180812/algal-bloom-a-problem-for-drinking-water-in-sweden

37. Urrutia-Cordero, P., Ekvall, M. K., \& Hansson, L. A. (2016). Local food web management increases resilience and buffers against global change effects on freshwaters. Scientific Reports, 6(February), 1-9. https://doi.org/10.1038/srep29542

38. Utermöhl, H. (1958). Zur Vervollkommnung der quantitativen Phytoplankton-Methodik. SIL Communications, 1953-1996. https://doi.org/10.1080/05384680.1958.11904091

39. Water Canada. (2018). Lake Erie Action Plan to Reduce Phosphorus Loads by 40\%. Retrieved May 23, 2018, from https://www.watercanada.net/lake-erie-action-plan-to-reduce-phosphorus-loads-by-40/

40. Water information system, S. (2019). Välkommen till VISS. Retrieved December 30, 2019, from https://viss.lansstyrelsen.se/

41. WHO. (2003). Cyanobacterial toxins: Microcystin-LR in Drinking-water Background document for development of WHO Guidelines for Drinkingwater Quality. Geneva. Retrieved from http://www.who.int/water_sanitation_health/dwq/chemicals/cyanobactoxins.pdf

42. Willén, E. (2001). Phytoplankton and water quality characterization: Experiences from the Swedish large lakes Mälaren, Hjälmaren, Vättern and Vänern. Ambio, 30(8), 529-537. https://doi.org/10.1579/0044-7447-30.8.529

43. Willén, T., \& Mattsson, R. (1997). Water-blooming and toxin-producing cyanobacteria in Swedish fresh and brackish waters, $1981-1995$. Hydrobiologia. https://doi.org/10.1023/A:1003047019422

44. World Health Organization. (2015). MANAGEMENT OF CYANOBACTERIA IN DRINKING-WATER SUPPLIES: Information for regulators and water suppliers. Geneva, Switzerland. WHO: Geneva, Switzerland. Retrieved from https://apps.who.int/iris/handle/10665/153970

45. Xu, H., Paerl, H. W., Qin, B., Zhu, G., Hall, N. S., \& Wu, Y. (2015). Determining critical nutrient thresholds needed to control harmful cyanobacterial blooms in eutrophic Lake Taihu, China. Environmental Science and Technology, 49(2), 1051-1059. https://doi.org/10.1021/es503744q

\section{Figures}




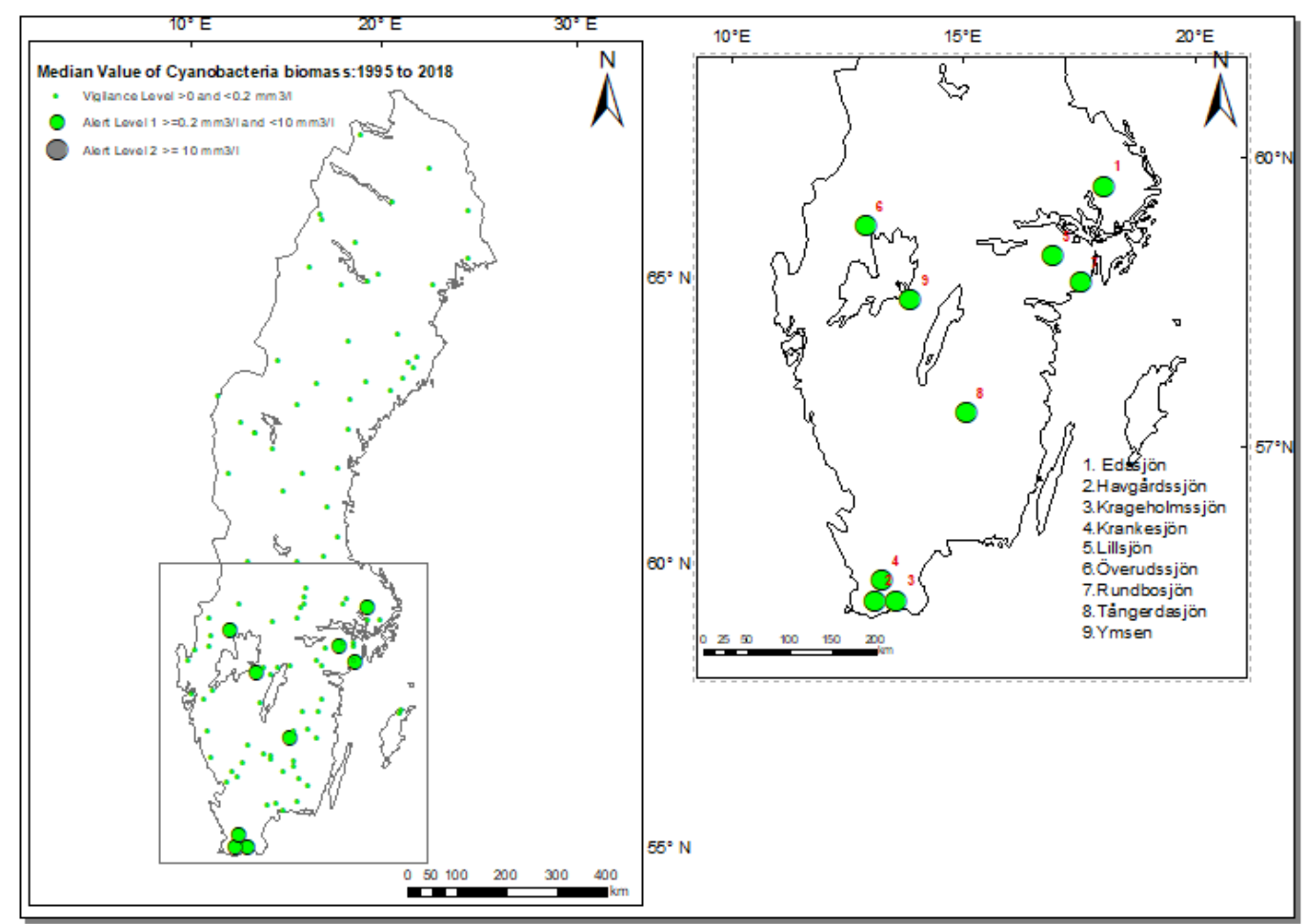

Figure 1

Swedish Trend lakes under environmental monitoring program; 9 lakes are selected for further study with regards to cyanobacteria occurrence.
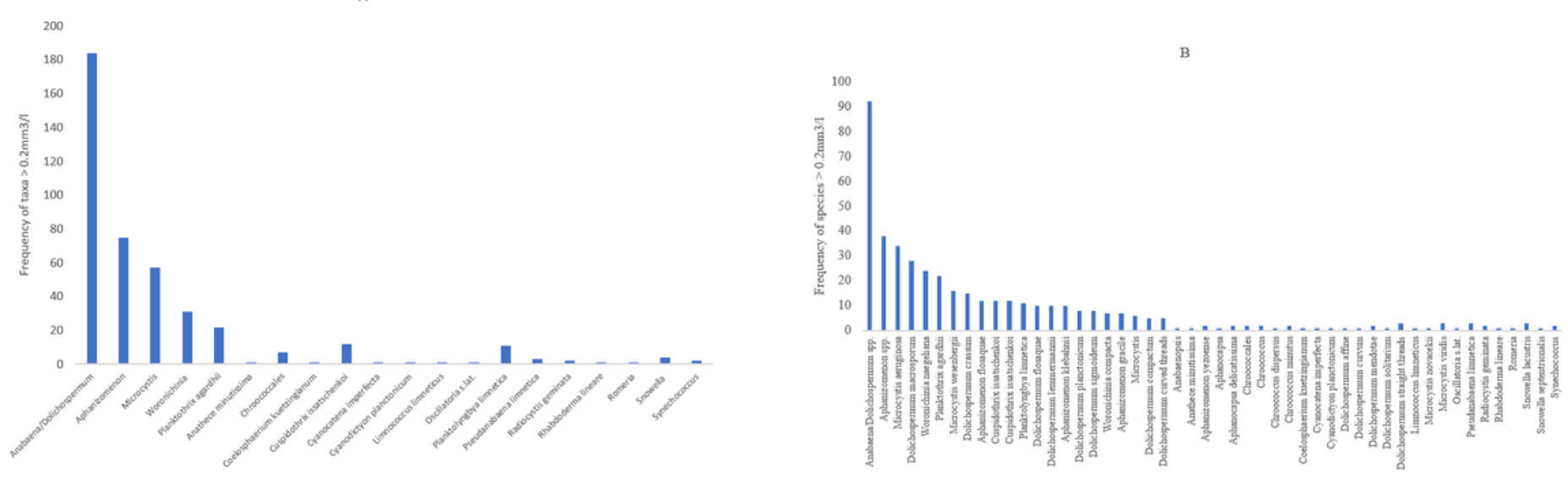

Figure 2

Cyanobacteria biovolume in the Swedish trend lakes, exceeding $0.2 \mathrm{~mm} 3 \mathrm{~L}-1$ (Drinking water alert level) divided into A) dominating taxa and B) dominating species. 


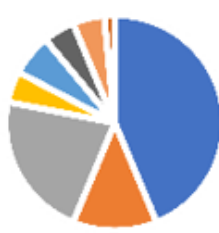

Krageholmssjön

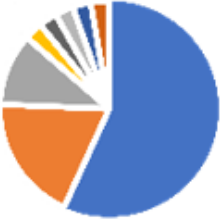

Havgårdssjön

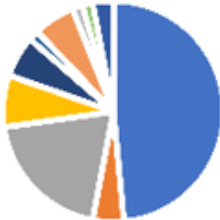

Ymsen
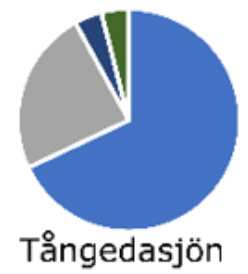

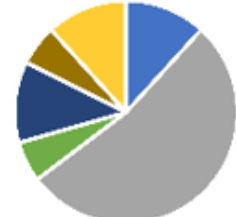

Krankesjön

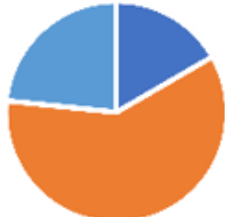

Edasjön

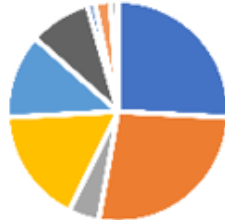

Lillsjön

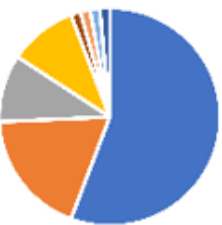

Överudssjön

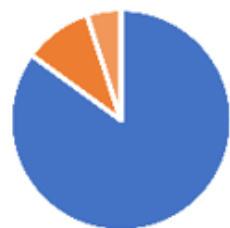

Rundbosjön

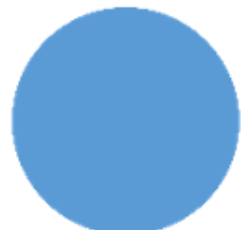

V. Rännöbodsjön

= Microcystis

- Anathece minutissima

- Planktothrix agardhii

- Coelosphaerium kuetzingianum $\mathbf{m}$ Cuspidothrix issatschenkoi

- Cyanodictyon planctonicum

- Limnococcus limneticus

- Cyanocatena imperfecta

- Planktolyngbya limnetica

= Pseudanabaena limnetica

- Rhabdoderma lineare

= Romeria

\section{Figure 3}

The diversity of species in all selected 9 lakes and one reference lake V. Rännöbodsjön.

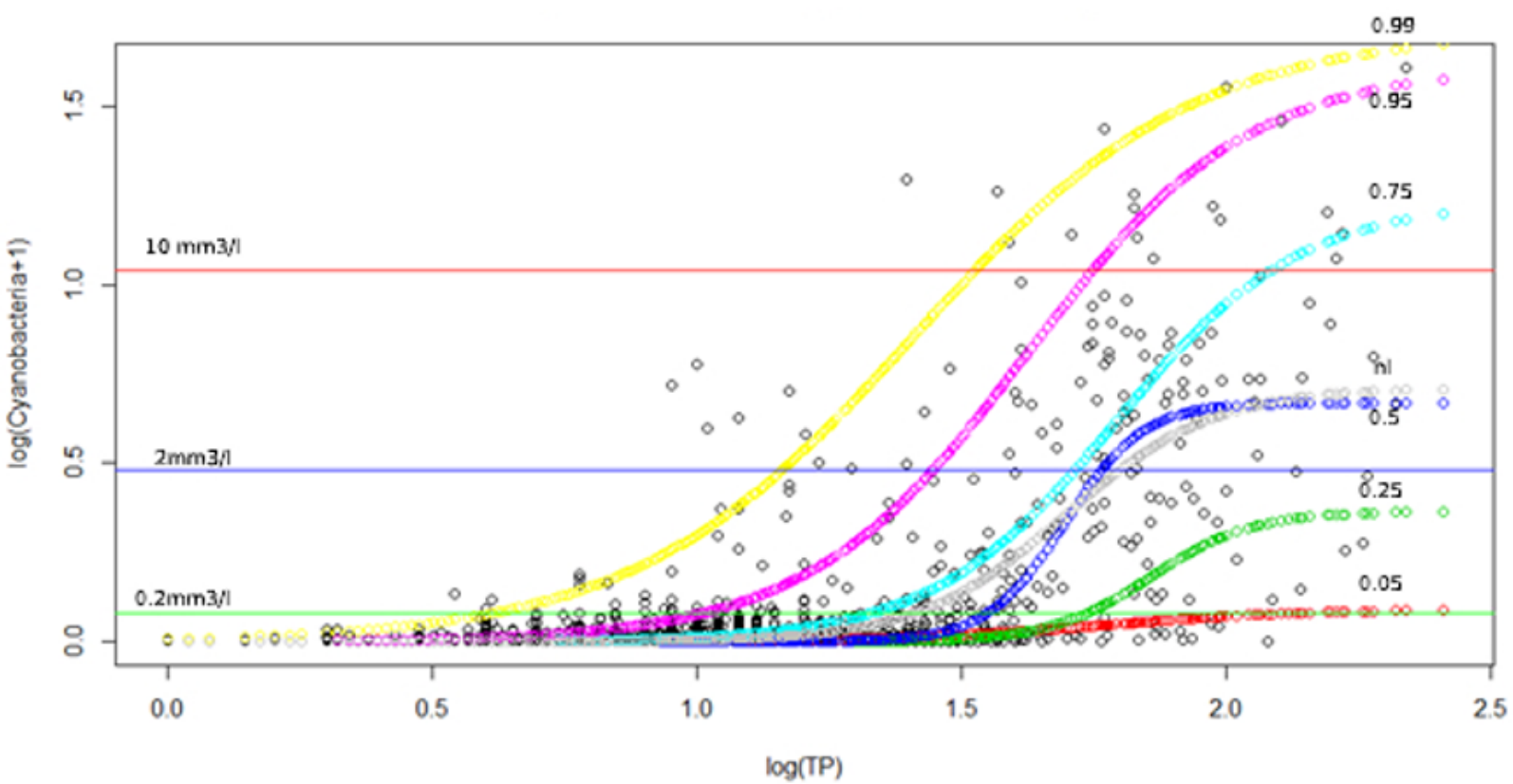

\section{Figure 4}

Scatter plot for log10(cyanobacteria+1) and $\log 10(T P)$ (Total phosphorus) for Swedish trend lakes ( $\mathrm{n}=108,1995$ to 2018 ). Quantile regression curves (0.05-0.99) using a fitted 3-parameter sigmoid nonlinear model are displayed. nls=nonlinear least square regression fit to mean of data. Thresholds relating to approximate WHO (1999) alert level 1 and 2 for drinking water are indicated together with thresholds relating to approximate low and medium health risk thresholds for recreational water. 